\title{
THE ROLE OF BANKING CAPITAL IN INDUSTRIAL SECTOR MICRO ENTERPRISES FOR POVERTY ALLEVIATION: A STUDY IN EAST JAVA, INDONESIA
}

\author{
Atik PURMIYATI*, Madeline BERMA**, Basri Abdul TALIB***, Marta Sabila RAKHIMA**** \\ *Airlangga University, INDONESIA \\ e-mail: atikpurmiyati@gmail.com \\ **, ***National University of Malaysia, MALEYSIA \\ **e-mail: madeline.berma@gmail.com \\ ***e-mail: basri@ukm.edu.my \\ ****LPEP Airlangga University, INDONESIA \\ e-mail: martasabila.r@gmail.com
}

\begin{abstract}
This study examines the micro enterprises of industrial sectors that receive Kredit Usaha Rakyat (People's Business Credit/KUR) or Commercial Credit (KK) in seven cities in East Java. Firstly, this study aims to measure the technical efficiency of micro enterprises in the industrial sector in East Java that accept KUR and KK using the Data Envelopment Analysis method; secondly, to examine the factors that influence the technical efficiency of micro enterprises, which receive KUR and KK with Tobit Regression. Unlike others' researches, this paper attempts to determine the influence of technical efficiency and other factors on the poverty status of micro entrepreneurs using logistic regression. The average technical efficiencies of KUR and KK recipient micro businesses using the assumptions of the DEA VRS model are 0.94 and 0.77 . While the average technical efficiencies of KUR and KK recipient micro businesses using the assumptions of the DEA CRS model are 0.88 and 0.71 . The factors that influence the technical efficiency of micro enterprises recipients of KUR and KK are profit, experience, geographical location, amount of credit, KUR access, the credit realization period, and dummy variable of food and beverage products. The factors that influence the poverty status of micro-entrepreneurs are technical efficiency, income, KUR access, gender, number of household member, and geographical location. The results of this research can be a material consideration for the government in formulating policies.
\end{abstract}

Keywords: micro credit, micro enterprise, poverty, technical efficiency.

JEL: O120, I32.

\section{$1 \quad$ Introduction ${ }^{1}$}

Poverty in Indonesia is still one of the main problems for the government. Various poverty reduction programs have been carried out since the Old Order government (1961-1965) until now, but the level of poor people is still fluctuating. The province that is the highest experiencing poverty is East Java with a poor population of 4,775,970 in 2015 (BPS, 2016). However, East Java also contributed GRDP to Indonesia in the second place after DKI Jakarta. This means that although East Java has a fairly high

\footnotetext{
${ }^{1}$ This article was submitted at the Asian Business and Economics International Conference 2019 (ABEIC 2019), Kangwon National University (KNU), Chuncheon, South Korea, April 2527, 2019 (https://submit.confbay.com/conf/abeic2019).
}

GRDP, it has the highest number of poor people. Hence, the government still has the duty to alleviate poverty in East Java.

There are many ways to alleviate poverty, one of which is by providing microcredit. Microcredit is given to poor people to help them form new businesses or to modify their existing businesses to be more developed and advanced (Johnson and Rogaly, 1997; Fasoranti, 2010). This step is carried out by the Indonesian government to alleviate poverty, namely Cluster III Poverty Program. Cluster III poverty reduction is by providing the KUR (People's Business Credit) program for Micro, Small and Medium Enterprises (TNP2K). The KUR program aims to strengthen MSME capital so that it can increase productivity and develop its business. In addition 
to the KUR program from the government, there are also other types of credit options for microenterprises, namely Commercial Credit (KK). This type of microcredit, KK is not a program from the government but one of the microcredit products provided by commercial banks. So, the type of credit application requirements is more complex and the interest is also higher than the KUR program. $\mathrm{KK}$ is another option for micro enterprises to obtain credit other than from the KUR program. However, both of them are options for microcredit to be provided for micro-enterprises.

Poor people mostly work in the informal sector such as micro-enterprises, one of them being the industrial sector. In 2015, the industrial sector became the main sector contributing to East Java's GRDP of $29.28 \%$ (BPS, 2016). As many as $92 \%$ of entrepreneurs in the industrial sector in East Java are dominated by MSMEs and SMEs (East Java Province). Based on the total number of MSMEs in East Java, 95.72\% are micro enterprises (East Java Cooperative and SME Office, 2014). However, according to the World Bank (2007), there are a number of common constraints faced by micro- enterprises including workers with low productivity, limited access to capital from banks, low profits due to high production costs, and difficulties in accessing markets.

To overcome the existing constraints, the government has provided micro credit facilities that can be used to increase productivity. Productivity in micro-enterprises can be improved through improving technical efficiency. The efficiency of microenterprises can be done by using existing inputs so that they can achieve maximum output. When micro enterprises' output is maximized and increases, it will also increase the income of microenterprises. When income increases, it can increase the welfare of micro entrepreneurs and alleviate poverty.

Previous research generally only discussed efficiency and determinants of efficiency, or determinants of poverty status. In this study, all three of these are discussed, starting from efficiency, determinants of efficiency, and determinants of poverty status. The purpose of this study is to determine the technical efficiency of KUR and KK recipient micro-enterprises by using Data Envelopment Anal- ysis, then to determine what factors influence the technical efficiency of micro-enterprises, and the last is to know whether the technical efficiency and other factors influence the poverty status of micro entrepreneurs. Based on this objective, it will be known that micro-enterprises' efficiency and the factors that affect technical efficiency can be used as evaluation materials to improve technical efficiency. In addition, by knowing the factors that influence the poverty status of micro entrepreneurs, it will be an evaluation material and consideration for the government in adopting policies to improve the welfare of micro entrepreneurs.

\section{$2 \quad$ Literature review}

\subsection{Microcredit}

Microcredit is given to poor people to help them make new businesses or to modify their existing businesses to be more developed and advanced (Johnson and Rogaly, 1997; Fasoranti, 2010). Kaboski and Townsend (2009) found that income, consumption, and investment in agriculture increased among recipients of microcredit, and increased income in a village in Thailand. A study by Sujarweni and Utami found that the KUR program was instrumental in increased performance in small and medium enterprises (SMEs) in Yogyakarta. The credit given to households to start a business affects the welfare of households (Quach, et al., 2005).

\subsection{Poverty}

Poverty is divided into two types, that is, absolute poverty and relative poverty. Absolute poverty is the number of people living below the minimum income level required to meet basic needs such as food, clothing, and home (Todaro and Smith, 2014). Meanwhile, relative poverty is a state of affairs, whereas income levels are capable of achieving a minimum level of basic needs but remain much lower than the surrounding communities (Esmara, 1986). The study of factors that influence poverty in Banten, Indonesia are: gender of family head, number of family members, level of education of the family head, occupation, and the type of credit used (Hayati, 2012). Dacuycuy and Lim (2014) in their study showed that the level of education, 
number of family members, composition of age of family members, ownership of health insurance affect poverty.

\subsection{Previous Study}

Based on a previous research, a study conducted by Charoenrat, Harvie and Amornkitvikai (2012) about the technical inefficiency factors for Thai manufacturing small enterprises reveals that firm age, skilled labor, firm location, ownership type, foreign investment and exporting influence manufacturing small enterprises' technical efficiency. Other research about technical efficiency of Manufacturing SMEs in Vietnam reveals that manufacturing SMEs in Vietnam have a relatively high average technical efficiency ranging from $84.2 \%$ to $92.5 \%$. The paper further examines the factors influencing efficiency. It finds that firm age, size, location, ownership, cooperation with a foreign partner, subcontracting, product innovation, competition, and government assistance are significantly related to technical efficiency, albeit with varying degrees and directions (Le and Harvie, 2010).

\subsection{Data Envelopment Analysis}

Data Envelopment Analysis (DEA) was first developed by Farrel (1957) and measures the technical efficiency of one input and one output into multi inputs and multi outputs by using relative efficiency values as input ratios (single virtual) and output (single virtual output). There are two models of approaches based on the relationship between input and output, namely the model of constant return to scale (CRS) and variable return to scale (VRS).

Constant return to scale (CRS) model according to Coelli, et al. (2005) is as follows:

$$
\begin{aligned}
& \min _{\theta, \lambda} \theta, \\
& \text { st }-q_{i}+Q \lambda \geq 0, \\
& \theta x_{i}-X \lambda \geq 0, \\
& \lambda \geq 0
\end{aligned}
$$

where $\theta$ is a scalar, and $\lambda$ is $I \times 1$ vector of constants.

The notation "st" stands for "subject to". The value of $\theta$ obtained is the efficiency of the i-micro enterprise with a value of $\theta \leq 1$, where a value of 1 indicates the point at the border, and hence, the company that is technically efficient according to Farrel (1957). It should be noted that the linear programming must be completed as many as 1 time, once for each micro enterprise in the sample. Then, the value of $\theta$ can be obtained from every micro enterprise.

According to Coelli, et al. (2005), the CRS assumption is valid for use if all companies operate on an optimal scale. However, imperfect competition, government regulations, financial constraints, and so on, can cause companies not to operate optimally. So, it is recommended to use the assumption of variable return to scale (VRS). The use of CRS assumptions when a company does not operate at an optimal scale will result in technical efficiency values that are confused by scale efficiency. Using the assumption of VRS can enable calculating technical efficiency without the effect of scale efficiency.

The model of the variable return to scale (VRS) based on Coelli, et al. (2005) is the following:

$$
\begin{aligned}
& \min _{\theta, \lambda} \theta, \\
& \text { st }-\mathrm{q}_{\mathrm{i}}+\mathrm{Q} \lambda \geq 0, \\
& \theta \mathrm{x}_{\mathrm{i}}-\mathrm{X} \lambda \geq 0, \\
& \mathrm{I} 1^{\prime} \lambda=1 \\
& \lambda \geq 0
\end{aligned}
$$

where I1 is an $\mathrm{I} \times 1$ vector of ones. This approach results in greater or equal technical efficiency scores using the CRS assumptions.

It is necessary to know that convexity constraints (I1' $\lambda=1)$ basically ensure that inefficient companies are only "benchmarked" against companies of the same size. These Convexity Constraints are not used in CRS assumptions so that in CRS, a company can be compared to a company that is substantially larger (smaller) than the company.

\subsection{Tobit Regression}

The Tobit regression model is known as a censored regression model or Tobit model, where the first model is reserved (Tobin, 1958). Regression is obtained by taking an average in previous relationships with the classical regression model. The general formula of the Tobit regression is as follows:

$$
\begin{aligned}
& y_{i}^{*}=x_{i}^{\prime} \beta+\varepsilon_{i}, \\
& y_{i}=0 \text { if } y_{i}^{*} \leq 0, \\
& y_{i}=y_{i}^{*} \text { if } y_{i}^{*}>0,
\end{aligned}
$$


where:

$\mathrm{y}_{\mathrm{i}}$ - dependent variable vector,

$\mathrm{y}_{\mathrm{i}}^{*}-$ dependent variable matrix $\mathrm{I} \times 1$,

$\mathrm{x}_{\mathrm{i}}^{\prime}$ - independent Variable Matrix,

$\beta$ - measuring vector coefficient $\mathrm{k} \times 1$ is unknown, where $\mathrm{k}$ is the number of parameters,

$\varepsilon_{\mathrm{i}}$ - residual models with normal distribution are filtered $\left(0, \sigma^{2}\right)$,

I $-1,2, \ldots$, I.

\subsection{Logistic Regression}

Logistic regression is one method used to model dependent variables that are categorical (nominal/ordinal in scale) based on one or more independent variables that can be categorical or continuous (interval/ratio scale) (Hosmer and Lemeshow, 2000). The logistic regression model is as follows (Hosmer and Lemeshow, 2000):

$$
\pi(x)=\frac{\exp \left(\beta_{0}+\beta_{1} x_{1}+\cdots+\beta_{p} x_{p}\right)}{1+\exp \left(\beta_{0}+\beta_{1} x_{1}+\cdots+\beta_{p} x_{p}\right)}
$$

where $p$ is the number of independent variables. To facilitate the estimation of regression parameters, the logistic regression model in equation (4) can be described using logit transforms from $\pi(\mathrm{x})$ to be as follows (Hosmer and Lemeshow, 2000, p.6):

$$
\mathrm{g}(\mathrm{x})=\beta_{0}+\beta_{1} \mathrm{x}_{1}+\cdots+\beta_{\mathrm{p}} \mathrm{x}_{\mathrm{p}}
$$

Equation (5) is a linear function of the parameters, with as many independent variables as $p$.

\section{$3 \quad$ Material and Methods}

\subsection{Data}

The data used in this study are primary data acquired through interviews in seven cities/districts in East Java in 2016. The cities are Kabupaten Gresik, Kabupaten Lamongan, Kabupaten Bojonegoro, Kota Pasuruan, Kabupaten Malang, Kota Kediri, and Kota Mojokerto, of which each city represents low, medium and high GRDP. Furthermore, the sample used in this study was obtained using the Slovin formula (Sevilla, et al., 1993) with a population of industrial sector micro enterprises in East Java as many as 356,047 micro-enterprises.

$$
\mathrm{n}=\mathrm{N} /\left(\mathrm{Nx} \mathrm{d}^{2}+1\right)
$$

where:

n - sample,

$\mathrm{N}$ - Population of Micro Enterprises,

$\mathrm{d}$ - degree of freedom,

$\mathrm{n}=356,047 /\left(356,047 \times 0.1^{2}+1\right)$,

$\mathrm{n}=78.07$.

Based on the calculation of the sample above, according to the Slovin formula, it takes at least 78 respondents. Therefore, the sample used in this study was 135 respondents.

\subsection{Analytical Approach and Variables}

In this study, three stages of analysis that were slightly different in the previous studies were used.

\begin{tabular}{|c|c|c|}
\hline Variables & Definition & Unit \\
\hline \multicolumn{3}{|l|}{ Output } \\
\hline $\mathrm{Y}$ & Net income of enterprises (in rupiah/month) & Rupiah \\
\hline \multicolumn{3}{|l|}{ Input } \\
\hline $\mathrm{X}_{1}$ & Capital & Rupiah \\
\hline $\mathrm{X}_{2}$ & Cost of raw materials for business activities (in rupiah/month) & Rupiah \\
\hline $\mathrm{X}_{3}$ & Supporting costs for business activities (in rupiah/month) & Rupiah \\
\hline $\mathrm{X}_{4}$ & Value of machine (in rupiah/month) & Rupiah \\
\hline $\mathrm{X}_{5}$ & Total manpower & Person \\
\hline
\end{tabular}

Table 1. Variables Input and Output in DEA Model

(Source: Authors' own research) 
This is because most previous studies only carried out a two-stage analysis to determine the efficiency and factors that affect efficiency or only analyzed the factors that affect poverty in micro-enterprises. The analysis of these three stages is still rarely found, so it is expected to contribute to the renewal of the methodology. Stage 1 analysis uses a Data Envelopment Analysis approach that aims to determine the efficiency of micro-enterprises in the industrial sector of KUR and KK recipients. Stage 2 uses Tobit regression to determine the factors that influ- ence the technical efficiency of the micro enterprises in the industrial sector. Finally, Stage 3 is to find out whether efficiency and other factors influence the poverty status of micro-enterprises.

Variables used in Data Envelopment Analysis are shown in Table 1.

Variables used in Tobit regression are shown in Table 2 .

Variables used in logistics regression are shown in Table 3.

Table 2. Variables for Tobit Regression Analysis

(Source: Authors' own research)

\begin{tabular}{|c|c|}
\hline Variables & Definition \\
\hline $\mathrm{D}_{1}$ & Food \& Beverage Enterprises \\
\hline $\mathrm{D}_{2}$ & Handicraft Enterprises \\
\hline $\mathrm{Z}_{1}$ & Profit/Net income (in rupiah) \\
\hline $\mathrm{Z}_{2}$ & Age of entrepreneur (in years) \\
\hline$Z_{3}$ & $\begin{array}{l}\text { Education: } \\
\qquad \begin{aligned} 1 & =\geq \text { Senior High School } \\
0 & =<\text { Senior High School }\end{aligned}\end{array}$ \\
\hline $\mathrm{Z}_{4}$ & Business Experience \\
\hline $\mathrm{Z}_{5}$ & Amount of assets for business \\
\hline $\mathrm{Z}_{6}$ & $\begin{array}{l}\text { Gender of Entrepreneur: } \\
\qquad \begin{array}{l}1=\text { Male } \\
0=\text { Female }\end{array}\end{array}$ \\
\hline $\mathrm{Z}_{7}$ & Labor \\
\hline $\mathrm{Z}_{8}$ & $\begin{array}{l}\text { Business Location: } \\
\qquad \begin{array}{l}0=\text { Rural } \\
1=\text { Urban }\end{array}\end{array}$ \\
\hline$Z_{9}$ & Amount of credit received \\
\hline$Z_{10}$ & $\begin{array}{l}\text { Access to the Kredit Usaha Rakyat (People's Business Credit) Program: } \\
\begin{array}{l}1=\text { Receive KUR } \\
0=\text { Non receive KUR }\end{array}\end{array}$ \\
\hline$Z_{11}$ & $\begin{array}{l}\text { Credit realization period: } \\
\qquad \begin{aligned} 1 & =\text { Credit realization } \leq 2 \text { weeks } \\
0 & =\text { Credit realization }>2 \text { weeks }\end{aligned}\end{array}$ \\
\hline
\end{tabular}


Table 3. Variables for Logistics Regression Analysis

(Source: Authors' own research)

\begin{tabular}{|l|l|}
\hline Variables & \\
\hline $\mathrm{D}_{1}$ & Food \& Beverage Enterprises \\
\hline $\mathrm{D}_{2}$ & Handicraft Enterprises \\
\hline $\mathrm{X}_{1}$ & Number of household members \\
\hline $\mathrm{X}_{2}$ & Business profit (in rupiah) \\
\hline $\mathrm{X}_{3}$ & Education: \\
& $1=\geq$ Senior High School \\
& $0=<$ Senior High School \\
\hline $\mathrm{X}_{4}$ & Geographical Location: \\
& $0=$ Rural \\
& $1=$ Urban \\
\hline $\mathrm{X}_{5}$ & House area (in $\mathrm{m}^{2}$ ) \\
\hline $\mathrm{X}_{6}$ & Gender of Household head: \\
& $1=$ Male \\
& $0=$ Female \\
\hline $\mathrm{X}_{7}$ & Household expenditure (in rupiah) \\
\hline $\mathrm{X}_{8}$ & Access to the Kredit Usaha Rakyat (People's Business Credit) Program: \\
& $1=$ Receive KUR \\
& $0=$ Non receive KUR \\
\hline $\mathrm{X}_{9}$ & Technical Efficiency: \\
& $1=0<$ TE $\leq 0.5$ \\
\hline & \\
\hline &
\end{tabular}

\section{$4 \quad$ Discussion and Results}

\subsection{Technical Efficiency of Micro Enterprises}

Table 4 shows that the number of industrial sector micro enterprises is 68 out of 135 entrepreneurs receiving KUR and 67 entrepreneurs receiving KK. The DEA calculation results for industrial sector micro enterprises that received KUR are in assumption of a variable return to scale (TE DEA-VRS), the average technical efficiency of industrial sector micro enterprises is 0.94 for the KUR receiver with its range of efficiency 0.4 to 1 and the rest is 0.15 . This value of efficiency means that the average performance that micro enterprises can achieve with the existing technology is $94 \%$ of the maximum potential results of this field.
The average gap between performance of the best micro enterprises and the other micro enterprises is about $16 \%$. In addition, the achievement of entrepreneurship income of industry businesses to KUR recipients may increase by about $16 \%$ to achieve maximum potential yield.

Furthermore, industry sector micro enterprises that received $\mathrm{KK}$ based on the DEA model assumed a variable return to scale (TE DEA-VRS), and the average technical efficiency was 0.77 within the range of 0.1-1 efficiency with standard deviation 0.23 . The average performance that entrepreneurs can achieve with existing technology is $77 \%$ of the maximum potential yield of this field. 
Table 4. Technical Efficiency of Industry Sector Micro Enterprises

(Source: Output data analysis)

\begin{tabular}{|c|c|c|c|c|c|c|c|c|c|c|}
\hline & \multicolumn{2}{|c|}{$\mathrm{N}$} & \multicolumn{2}{|c|}{ Average } & \multicolumn{2}{|c|}{ Min } & \multicolumn{2}{|c|}{ Max } & \multicolumn{2}{|c|}{ Standard Deviation } \\
\hline & KUR & KK & KUR & KK & KUR & KK & KUR & KK & KUR & $\mathrm{KK}$ \\
\hline TE-DEA VRS & 68 & 67 & 0.94 & 0.77 & 0.4 & 0.1 & 1 & 1 & 0.15 & 0.23 \\
\hline TE-DEA CRS & 68 & 67 & 0.88 & 0.71 & 0.18 & 0.09 & 1 & 1 & 0.2 & 0.24 \\
\hline $\begin{array}{l}\text { Information: } \\
\text { TE- DEAVRS = } \\
\text { TE- DEA CRS = }\end{array}$ & chnica & & Con & Ret & Scale & & & & & \\
\hline
\end{tabular}

The average gap between the performance of the best micro enterprise and the other micro enterprise is $23 \%$ for $\mathrm{KK}$ recipients. The performance achievement of industry sector micro enterprises of KK recipient may increase by $23 \%$ to achieve the maximum potential yield.

The average of technical efficiency of KUR and KK credit receivers using a constant return to scale (CRS) ranges from 0.88 and 0.71 , respectively, within the range of efficiency $0.18-1$ and $0.09-1$ with standard deviation 0.2 and 0.24 (Table 4). This suggests that KUR and KK's micro-enterprises generate $88 \%$ and $71 \%$ of potential output using CRS. Based on the value of CRS efficiency, the achievement of KUR and KK technical efficiency of micro enterprises can still increase by about $12 \%$ and $29 \%$ respectively.

Micro enterprises that received KUR and KK can be divided into seven classes and eight classes of technical efficiency distribution, respectively with a distribution mix of between 0.18 to 1 and 0.09 to 1 with a range of 0.12 . At the industry sector micro enterprises that received KUR, at 1st class with interval 0.18 to $0.3,2$ nd class with interval of 0.31 to 0.43 , and then up to grade 7 with technical efficiency distribution 1 . Next to the 1 st class KK recipient enterprises with intervals of 0.09 to 0.17 , the class 2 with interval of 0.18 to 0.3 , further up to class 8 with the distribution of technical efficiencies 1 .

Fig. 1 indicates the estimates of DEA-VRS and CRS by showing that the $100 \%$ efficient KUR receiver of micro enterprises (TE $=1)$ can be achieved with 53 and 35 enterprises respectively, or $78 \%$ and $51.5 \%$ of the total industry enterprises. On the other hand, the technical efficiency level at the range 0.10.99 , there are 15 enterprises (22\%) with VRS and 33 enterprises $(48.5 \%)$ with CRS. This explains that there are still many micro-enterprises that are technically inefficient.

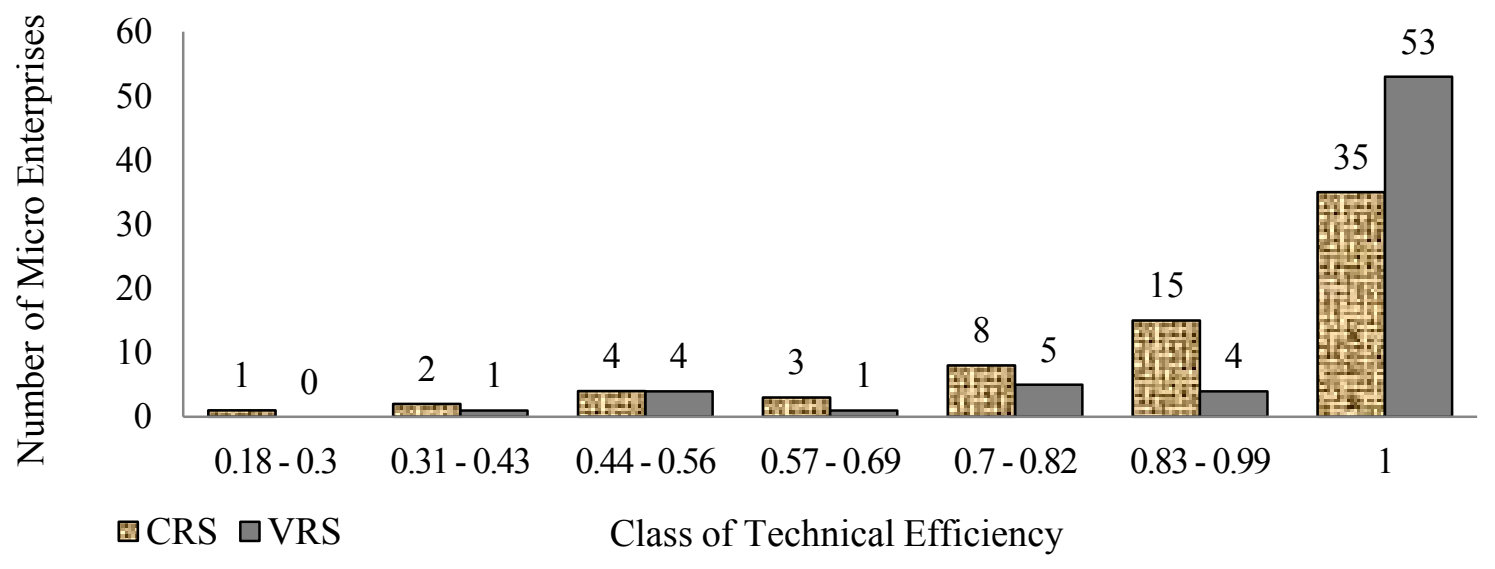

Figure 1. Distribution of Technical Efficiency of Micro Enterprises Receiving KURs in Industrial Sector Based on the Assumption of CRS and VRS

(Source: Output data analysis) 
Micro enterprises of the industry sector that received KK have a technical efficiency distribution shown in Figure 2. Micro enterprises that are $100 \%$ efficient with DEA-VRS and CRS can be achieved with only 18 and 9 enterprises, or $27 \%$ and $13 \%$ of the enterprise value of the total number of micro enterprises in this industry sector. The rest efficiencies of micro enterprises in industry sector, at the $0.7-0.99$ range of micro enterprises with the assumptions of DEA
VRS and CRS, that is, 28 (42\%) and 33 (49\%), respectively. Finally, the efficiency distribution of micro enterprises industry sector at the range $0.1-$ 0.69 , that is, $21(31 \%)$ with VRS and $25(38 \%)$ with CRS. Based on that distribution, the micro enterprise should increase the amount of production output generated, so that technical efficiency increases.

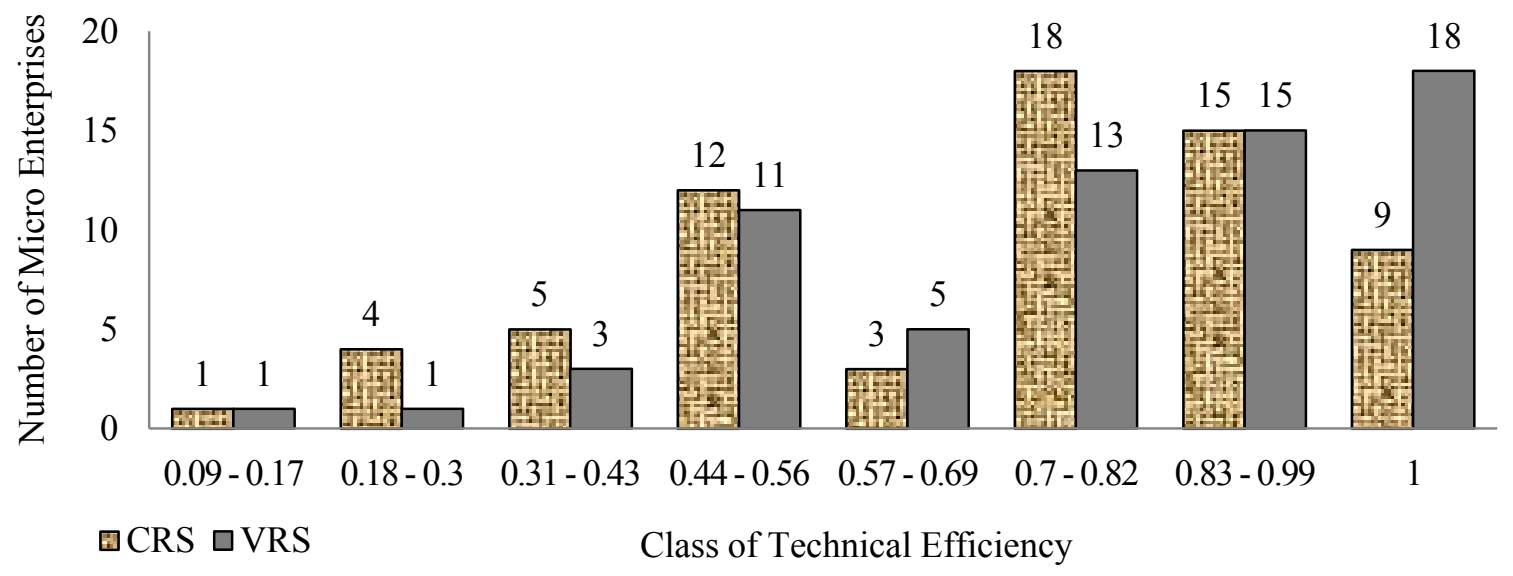

Figure 2. Distribution of Technical Efficiency of Micro Enterprises Receiving KKs in Industrial Sector Based on the Assumption of CRS and VRS (Source: Output data analysis)

\subsection{Determinants of Factors of Technical Efficiency}

Tobit regression analysis of industrial sector micro enterprises for efficiency determinants can be seen in Table 5. The results of the Likelihood Ratio (LR) test results in a statistical value of LR 369.53 with a probability value of 0.000 less than $\alpha(0.01)$. This means that $\mathrm{HO}$ is rejected, that is, the independent variables simultaneously have a significant effect on technical efficiency at the level of 0.01 significance.

Table 5. Maximum Likelihood Estimation of Tobit Regression

(Source: Output data analysis)

\begin{tabular}{|l|l|l|c|c|c|}
\hline \multicolumn{1}{|c|}{ Variables } & Code & dy/dx & $\begin{array}{c}\text { Standard } \\
\text { Deviation }\end{array}$ & Z-Statistic & Probability \\
\hline Constant & $\mathrm{C}$ & 0.2 & 0.04 & 5.45 & $0.000^{*}$ \\
\hline Food \& Beverage & $\mathrm{D}_{1}$ & 0.03 & 0.016 & 1.84 & $0.07^{*}$ \\
\hline Handicraft & $\mathrm{D}_{2}$ & 0.001 & 0.015 & 0.07 & 0.94 \\
\hline Profit & $\mathrm{Z}_{1}$ & 0.13 & 0.002 & 5.35 & $0.000^{*}$ \\
\hline Age & $\mathrm{Z}_{2}$ & 0.0001 & 0.0005 & 0.24 & 0.81 \\
\hline Education & $\mathrm{Z}_{3}$ & 0.004 & 0.016 & 0.26 & 0.8 \\
\hline Experience & $\mathrm{Z}_{4}$ & 0.032 & 0.006 & 5.39 & $0.000^{*}$ \\
\hline Asset & $\mathrm{Z}_{5}$ & -0.0009 & 0.0007 & -1.26 & 0.2 \\
\hline Gender & $\mathrm{Z}_{6}$ & -0.0009 & 0.012 & -0.08 & 0.93 \\
\hline
\end{tabular}


Table 5. Maximum Likelihood Estimation of Tobit Regression (cont.) (Source: Output data analysis)

\begin{tabular}{|l|c|c|c|c|c|}
\hline \multicolumn{1}{|c|}{ Variables } & Code & $\mathrm{dy} / \mathrm{dx}$ & $\begin{array}{c}\text { Standard } \\
\text { Deviation }\end{array}$ & Z-Statistic & Probability \\
\hline Labor & $\mathrm{Z}_{7}$ & -0.0003 & 0.006 & -0.06 & 0.95 \\
\hline Geographical Location & $\mathrm{Z}_{8}$ & 0.019 & 0.011 & 1.7 & $0.09^{*}$ \\
\hline Amount of Credit & $\mathrm{Z}_{9}$ & 0.0009 & 0.0003 & 2.75 & $0.007^{*}$ \\
\hline KUR Access & $\mathrm{Z}_{10}$ & 0.04 & 0.01 & 2.06 & $0.042^{*}$ \\
\hline Credit Realization Period & $\mathrm{Z}_{11}$ & 0.033 & 0.019 & 1.69 & $0.094^{*}$ \\
\hline LR & & & & 369.53 & $0.000^{*}$ \\
\hline Log Likelihood & & & 107.17 & \\
\hline *Significance at the level $\alpha(0.1)$ & & & & \\
\hline
\end{tabular}

Based on partial test, there are seven independent test results, namely, profit, experience, business location, amount of credit, KUR access, the credit realization period, and dummy variable of food and beverage products that have a positive and significant influence on the technical efficiencies-industrial enterprises on the level of significance 0.1 . However, there are six independent variables that do not have a significant effect on the technical efficiency, that is age, education, asset, gender, and labor and also dummy variable of handicraft products. This shows that based on the evidence, statistical probability of age, education, asset, gender, labor, and dummy variable of handicraft products are more than $\alpha(0.1)$.

\subsection{Determinants of Factors of Poverty Status}

Estimation of factors that determine poverty status of industrial sector micro enterprises using logistics regression are shown in Table 6.

Table 6. Maximum Likelihood Estimation of Logistics Regression

(Source: Output data analysis)

\begin{tabular}{|l|c|c|c|c|c|c|}
\hline \multicolumn{1}{|c|}{ Variables } & Code & $\begin{array}{c}\text { Odds } \\
\text { Ratio }\end{array}$ & Coefficient & $\begin{array}{c}\text { Standard } \\
\text { Deviation }\end{array}$ & Z-Statistic & Probability \\
\hline Constant & $\mathrm{C}$ & 0.56 & -0.57 & 2.5 & -0.23 & 0.82 \\
\hline Food \& Beverage Products & $\mathrm{D}_{1}$ & 0.16 & -1.81 & 1.26 & -1.44 & 0.15 \\
\hline Handicraft & $\mathrm{D}_{2}$ & 7.68 & 2.04 & 1.2 & 1.7 & $0.09^{*}$ \\
\hline Technical Efficiency & $\mathrm{X}_{11}$ & 10.24 & 2.32 & 0.98 & 2.37 & $0.02^{*}$ \\
\hline Number of Household member & $\mathrm{X}_{12}$ & 0.19 & -1.66 & 0.5 & -3.53 & $0.000^{*}$ \\
\hline Income & $\mathrm{X}_{13}$ & 1.14 & 0.13 & 0.05 & 2.64 & $0.008^{*}$ \\
\hline KUR Access & $\mathrm{X}_{14}$ & 11.6 & 2.45 & 0.81 & 3 & $0.003^{*}$ \\
\hline Education & $\mathrm{X}_{15}$ & 0.8 & -0.22 & 0.8 & -0.28 & 0.78 \\
\hline Expenditure & $\mathrm{X}_{16}$ & 1.02 & 0.02 & 0.034 & 0.6 & 0.55 \\
\hline Gender & $\mathrm{X}_{17}$ & 43.21 & 3.76 & 0.98 & 3.82 & $0.000^{*}$ \\
\hline Geographical Location & $\mathrm{X}_{18}$ & 5.5 & 1.7 & 0.84 & 2.03 & $0.04^{*}$ \\
\hline House Area & $\mathrm{X}_{19}$ & 0.98 & -0.011 & 0.01 & -1.11 & 0.26 \\
\hline LR & & & & 131.33 & $0.000^{*}$ \\
\hline Log Likelihood & & & & -26.83 & \\
\hline *Significance at the level $\alpha(0.1)$ & & & & \\
\hline
\end{tabular}


The Likelihood Ratio (LR) test yields a statistical value of LR 131.33 with a probability value of 0.000 less than $\alpha(0.01)$. Based on the findings of the LR test, the null hypothesis $\left(\mathrm{H}_{0}\right)$ states that the independent variables simultaneously have no effect on the dependent variable $\left(\mathrm{H}_{0}: \beta_{1}=\beta_{2}=\ldots . .=\beta_{\mathrm{k}}=\right.$ 0 ) is rejected by $\mathrm{H}_{0}$. In other words, independent variables simultaneously have a significant effect on poverty status at the 0.01 level of significance.

Based on partial test of logistics regression findings that six out of eleven independent variables showed a significant positive impact on poverty status at the significance level of 0.1 . Hence, the technical efficiency, income, KUR access, gender and geographical location have a positive and significant impact on the poverty status of the entrepreneur, while the number of household members shows a significant negative impact on the status of poverty.

Education, expenditure, location house area and dummy variable of food and beverage products in the industrial sector have no significant effect on poverty status based on evidence that the statistical probability $\mathrm{z}$ for education (0.78), expenditure (0.55), house area (0.26) and dummy variable of food and beverage products $(0.15)$ is greater than $\alpha(0.1)$.

\section{Conclusion}

The DEA calculation results of industrial sector micro enterprises KUR receiver indicate that based on the assumption, the variable return to scale (TE DEA-VRS) has an average technical efficiency of 0.94, with efficiency range 0.4-1, and standard deviation 0.15 . Conversely, the average technical efficiency of the KUR credit-receiver using a constant return to scale (CRS) was from 0.88 within the range of efficiency $0.18-1$, with standard deviation 0.2. Furthermore, technical efficiency of industrial sector micro enterprises of the KK receivers based on the DEA variable return to scale assumption (TE DEA-VRS) have an average technical efficiency of 0.77 within the range of $0.1-1$ efficiency, with standard deviation of 0.23 . The average technical efficiency of a KK-receiver using a constant return to scale (CRS) is 0.71 , within the range of efficiency
$0.09-1$ with standard deviation 0.24 . These results indicate that there is still need for improvements in the management of KUR or KK recipient microenterprises by utilizing existing inputs in order to obtain maximum output. This improvement can be accomplished by reducing or adding inputs adjusting to the type of micro-enterprises.

Determinants of the technical efficiency of microenterprises in the industrial sector based on Tobit regression analysis are profit (Khai and Yabe, 2011), experience (Abu and Kirsten, 2009; Wongkeawchan, et al., 2000), geographical location (Akhmad, 1996), amount of credit (Dell'Atti, Paselli and Mazzarelli, 2013), KUR access (Sujarweni and Utami, 2015), the credit realization period (Kotler and Keller, 2009), and dummy variable of food and beverage products that have a positive and significant influence on the technical efficiencies-industrial enterprises on the level of significance 0.1. Experience will reveal a person's potential. Full potential will gradually emerge from time to time in response to various experiences (Johnson, 2007).

The location of micro enterprises determines efficiency. If micro enterprises are located close to raw materials, it will be easier and faster in the implementation of the production process. If the micro business location is closer to the customer, it will increase the ease in selling micro enterprises products. The larger amount of credit can be used for working capital and financing the production process by adding inputs so that it can increase production output.

Determinant factors of the poverty status of industrial sector micro entrepreneurs are technical efficiency (Carter, 2008), income (Janjua and Kamal, 2011), KUR access (Quach, et al., 2005), gender (Litchfield and Mc Gregor, 2008), number of household member (De Silva, 2008) and geographical location (Dacuycuy and Lim, 2014), which have a significant effect on the poverty status of entrepreneur. Variables such as income growth per capita, reducing income inequality and education play an important role in poverty eradication (Janjua and Kamal, 2011). The ease of obtaining KUR with low interest can help the micro enterprises' capital for the poor to increase their income without being burdened with high interest and installments. The number of house- 
hold members also affects the increase in family costs significantly in all aspects of expenditure (De Silva, 2008).

The contribution of this research discusses the relationship between technical efficiency, determining factors of technical efficiency and poverty eradication. Based on the results of efficiency, it will be an evaluation for micro-enterprises to be able to improve their enterprises' efficiency. Increased efficiency can be achieved by examining the factors that influence the technical efficiency of microenterprises. The government in this case is the Department of Cooperatives and Small Medium Enterprises, which by knowing the efficiency of micro enterprises, can provide assistance to micro enterprises that receive KUR and KK in order to increase the efficiency of production and sales of their products. Then, the results of analyzing the factors that influence the poverty status of micro entrepreneurs can be a material consideration for the government in formulating policies to reduce poverty. In addition, by knowing the role of KUR in determining poverty status, the government can use it to decide on the continuation of the KUR program in the future. In further research, it is recommended to add more samples and regions to be sampled. Additionally, the method of analysis can be improved with other newer methods such as nonparametric envelopment of data stochastic, which is a combined method between SFA and DEA.

\section{References}

[1] Abu, O., Kirsten, J.F., 2009. The South African Maize Milling Industry: Can Small and Mediumscale Maize Milling Enterprise Survive and Thrive? (No. 1005-2016-79088).

[2] Akhmad, J., 1996. Analisis faktor-faktor yang mempengaruhi perilaku konsumen warung lesehan di jalan protokol Yogyakarta (Analysis of Factors Affecting Consumer Behavior Warung Lesehan in Yogyakarta). Jurnal STIE Widya Wiwaha Kajian Bisnis, 9(7), pp.14-28.

[3] Carter, W.K., (2008). Akuntansi Biaya (Cost Accounting). 14th ed. Jakarta: Salemba Empat.

[4] Charoenrat, T., Harvie, C., Amornkitvikai, Y., 2013. Identifying Technical Inefficiency Factors for Thai Manufacturing Small Enterprises. ICSB World Conference Proceedings, 2(2), p.1.

[5] De Silva, I., 2008. Micro-level Determinants of Poverty Reduction in Sri Lanka: A Multivariate Approach. International Journal of Social Economics, 35(3), pp.140-158.

[6] Le, V., Harvie, C., 2010. Technical Efficiency of Manufacturing SMEs in a Transitional Economy: Evidence from Vietnam. ICSB World Conference Proceedings, p.1.

[7] Badan Pusat Statistik, 2016. Number of Poor Population Based on Province, 2007-2015. [online] Available through: <https://www.bps. go.id/linkTableDinamis/view/id/1119>.

[8] Badan Pusat Statistik, 2016. Gross Regional Domestic Product of Provinces in Indonesia by Business Field 2012-2016. [online] Available through: <https://www.bps.go.id/publication/ 2017/07/25/7b4769be49b4a14b664f00fc/produk -domestik-regional-bruto-provinsi-provinsi-diindonesia-menurut-lapangan-usaha-20122016.html>.

[9] Bayudan-Dacuycuy, C., Lim, J.A., 2014. Chronic and Transient Poverty and Vulnerability to Poverty in the Philippines: Evidence Using a Simple Spells Approach. Social Indicators Research, 118(1), pp.389-413.

[10] Coelli, T.J., Rao, D.S.P., O'Donnell, C.J., Battese, G.E., 1996. An Introduction to Efficiency and Productivity Analysis. USA: Springer.

[11] Dell'Atti, S., Pacelli, V., Mazzarelli, G., 2015. The Efficiency of the European Banking Groups and its Determinants. Managerial Finance, 41(7), pp.734-751.

[12] Esmara, H., 1986. Perencanaan dan Pembanqunan di Indonesia (Planning and Development in Indonesia). Jakarta: PT Gramedia.

[13] Farrell, M.J., 1957. The Measurement of Productive Efficiency. Journal of the Royal Statistical Society Series A. 120(3), pp.253-290.

[14] Fasoranti, M.M., 2010. The Influence of MicroCredit on Poverty Alleviation Among Rural Dwellers: A Case Study of Akoko North West Local Government Area of Ondo State. African Journal of Business Management. 4(8), pp.14381446.

[15] Gebremariam, G.H., Gebremedhin, T.G., Jackson, R.W., 2004. The Role of Small Business 
in Economic Growth and Poverty Alleviation in West Virginia: An Empirical Analysis. The Paper at the American Agricultural Economics Association Annual Meeting, Denver. Colorado, August, 1(4).

[16] Hayati, A., 2012. Analisis Resiko Kemiskinan Rumah Tangga di Provinsi Banten (Risk Analysis of Household Poverty in Banten Province). Thesis. Faculty of Economics University of Indonesia: Jakarta.

[17] Hosmer, D.W., Lemeshow, S., 2000. Applied Logistic Regression. 2nd ed. Canada: John Wiley \& Sons, Inc.

[18] Janjua, P.Z., Kamal, U.A., 2011. The Role of Education and Income in Poverty Alleviation: A Cross-Country Analysis. The Lahore Journal of Economics, 16(1), p.143.

[19] Johnson, S., Rogaly, B., 1997. Microfinance and poverty reduction. Oxfam.

[20] Johnson, E.B., 2007. Contextual Teaching and Learning. Bandung: MLC.

[21] Kaboski, J.P., Townsend, R.M., 2000. Policies and Impact: An Analysis of Village-Level Microfinance Institutions. Journal of the European Economic Association, 3(1), pp.1-50.

[22] Khan, N., Akhtar, S., Khan, M., Naz, S., Tanveer, J., Kaleem, M., 2017. Maize productivity enhancement through credit program of Zari Tarqiati Bank Limited in rural areas of District Mardan. Sarhad Journal of Agriculture, 33(1), pp.139-143.

[23] Khai, H.V., Yabe, M., 2011. Technical Efficiency Analysis of Rice Production in Vietnam. Journal ISSAAS, 17(1), pp.135-146.
[24] Khandker, S.R., 1998. Fighting Poverty with Microcredit: Experience in Bangladesh. Oxford University Press.

[25] Kotler, P., Keller, K.L., 2009. Manajemen Pemasaran (Marketing Management). 13th ed. Jakarta: Erlangga.

[26] Litchfield, J., McGregor, T., 2008. Poverty in Kagera, Tanzania: Characteristics, Causes and Constraints. Poverty Research Unit at Sussex, University of Sussex.

[27] Quach, M., Mullineux, A., Murinde, V., 2005. Access to Credit and Household Poverty Reduction in Rural Vietnam: A cross-sectional study. The Birmingham Business School, The University of Birmingham Edgbaston, pp.1-40.

[28] Sujarweni, V.W., Utami, L.R., 2015. Analisis Dampak Pembiayaan Dana Bergulir KUR (Kredit Usaha Rakyat) terhadap Kinerja UMKM (Studi Kasus di Daerah Istimewa Yogyakarta). Jurnal Bisnis dan Ekonomi, 22(1).

[29] Tobin, J., 1958. Estimation of Relationships for Limited Dependent Variables. Econometrica: Journal of the Econometric Society, pp.24-36.

[30] Todaro, M.P., Smith, S.C., 2014. Human Capital: Education and Health in Economic Development. Economic Development. United Kingdom.

[31] Wongkeawchan, J., Wiboonpongse, A., Sriboonchitta, S., Huang, W.T., 2000. Comparison of Technical Efficiency of Rice Mill Systems in Thailand and Taiwan. Ph.D. Taiwan: Chiang Mai University. 